\title{
A globális, az európai uniós vírusválság határpolitikai hatásai
}

\author{
Allambatárok régi-új szerepben \\ a Kárpát-medencében, 2020-2021
}

\author{
Hajdú Zoltán \\ Közgazdaság- és Regionális Tudományi Kutatóközpont Regionális Kutatások Intézete, \\ Dunántúli Tudományos Osztály, Pécs, Magyarország \\ Beérkezett: 2021. július 16.; Elfogadva: 2021. július 28.
}

\begin{abstract}
Összefoglalás
Az elmúlt mintegy másfél év alatt a COVID-19 vírus valójában több struktúrában megrengette a világot, az Európai Uniót és egyes országokat is. A világ államai rövid idő alatt bezárkóztak, az Európai Unió 30 napra lezárta külső határait, az egyes tagállamok pedig az uniós belső határokat is lezárták. Veszélybe került a schengeni rendszer. A Kárpát-medence államai az első́k között reagáltak a határok lezárásával. Az egyéni döntések kritikája erőteljesen megjelent az Európai Bizottság részéról. A globális, az európai és a szomszédállami folyamatok összefüggtek. A határok lezárása feltehetően hozzájárult a vírus terjedésének a korlátozásához. (Ausztrália példája ezt erósíti.) A határzárak a nemzetközi tranzitforgalomban, a határ menti területeken élók és az ingázók között okozták a legnagyobb bizonytalanságot, több esetben zúrzavart.
\end{abstract}

Kulcsszavak: COVID-19, globális államhatár-folyamatok, az Európai Unió válaszai, a külső és a belső államhatárok lezárása, a Kárpát-medencén belüli határzárások

\section{The border policy effects of the global and EU virus crises \\ State borders in old and new role in the Carpathian Basin, 2020-2021 \\ Zoltán Hajdú}

Research Centre for Economic and Regional Studies, Institute of Regional Studies, Pécs, Hungary

\section{Summary}

According to the first 'official announcement' in December of 2019 the Covid-19 virus is reported to have emerged in China. The global spread of the virus was extremely fast. On 11 March 2020, the WHO declared Covid-19 to be a global pandemic. As of 31 March 2020 about $91 \%$ of the world population lived in countries with border and travel restrictions (border-closed world). The brief analysis reviews the main processes affecting EU and Member States borders, with a special regard to Hungary and its neighbours in the Carpathian Basin. On 17 March 2020, the EU closed its external borders for 30 days.to non-EU citizens. In parallel, a number of Member States decided to close their borders to both Schengen Zone members and third countries. As a response to border closures, the EU Commission and some states organized the repatriation of about 600,000 EU citizens. On 4 March, virus was officially reported to have been detected in Hungary. On 11 March the Hungarian Government declared a national state of emergency. On 15 March the first coronavirus-related death was announced. On 16 March the Government ordered the complete closure of Hungarian borders. After a border 'traffic chaos' along the Austrian-Hungarian border, the Hungarian Government - with collaborations with Romania - opened humanitarian corridors for foreign citizens. The possibilities of border crossings of citizens of seven neighbours of Hungary were formed not just by Hungary. In 2020 because of different changes (modifications, opening and closing) we could form at least three categories: open borders, partly open borders, closed borders. In the neighbouring countries (Austria, Slovakia, 
Ukraine, Romania, Serbia, Croatia, Slovenia) the progression of the epidemic followed the same pattern. Over the past year and a half the virus crisis has actually shaken many structures of the globalized world, the European Union and many countries in the Carpathian Basin. The virus crises has disrupted intensive connections between Hungary and neighbouring countries. Neither Hungary nor its neighbours were able to insulate themselves from the epidemic waves. The border restrictions primarily affected the movements of persons. Because of 'permanent uncertainty' commuters were the losers of the crisis.

Keywords: Covid-19, border-closed world, EU border policies, Hungary on borders, different border policies in the Carpathian Basin

\section{Bevezetés}

A koronavírus Kínában ütötte fel a fejét (a titkolózások miatt pontosan nem lehet tudni, hogy milyen módon alakult ki, s mikor), s onnan indult el feltehetően 2019 decemberétől. Rövid időn belül eljutott szinte minden kontinensre és országba. A vírus „zilált állapotban találta” a globalizált világot, Donald Trump amerikai elnök az USA pozícióinak mindenre kiterjedő javítását tűzte ki céljául, kereskedelmi háborúba bonyolódott Kínával. Az Európai Unió legfontosabb „ügye” hosszú időn keresztül a Brexit és a külső tömeges migráció kérdésének a kezelése volt. A vírus megjelenésekor az új Európai Parlament és az új Európai Bizottság még alig állt munkába. Több országban belpolitikai válságok voltak, kevéssé múködőképes kormányok tevékenykedtek. Miniszterelnökök, miniszterek buktak bele a vírusválság kezelésébe, illetve az ahhoz kapcsolódó ügyekbe.

Magyarország a tekintetben kivételt képezett, hogy a kormányzat erős parlamenti felhatalmazással rendelkezett a vírus megjelenésének időpontjában, ugyanakkor az egészségügyi intézményrendszer, az egészségügy személyi és technikai infrastruktúrája nem állt készen ilyen nagyságrendü feladatok ellátására. A vírus terjedésével párhuzamosan kellett megteremteni a vele szembeni védekezés és kezelésének személyi és közösségi eszközrendszerét.
Rövid elemzésemben arra vállalkozom, hogy az élet szinte minden területén rövid idő alatt mély válságokat eredményező járvány (csak érintem magukat az adatokat) hogyan hatott a különböző országok államhatár- és határellenőrzési politikájára, hogyan reagált a helyzet változásaira az EU, milyen lépéseket tett Magyarország, mit és hogyan szabályoztak a szomszédos országok. (A reakciók egyes esetben pánikszerúek voltak, több országban elöfordult, hogy egy napon belül is változtak a szabályok.)

\section{Másfél év a vírus árnyékában, amely megrengette a világot}

A vírus veszélyességét kezdetben csak a virológus szakma ismerte fel, még a vezető politikusok egy része is lekicsinyelte a vírus potenciális közegészségügyi, gazdasági, társadalmi, biztonságpolitikai kockázatait. A vírus nem egyszerúen globális, hanem szinte totális megjelenése (nemcsak a szárazföldön, hanem az óriási nagyságú és befogadó kapacitású óceánjáró üdülő hajókon, repülőgép-anyahajókon, sőt atom-tengeralattjárókon is megjelent) döbbentette rá a világ politikai elitjének nagy részét arra, hogy a járvány óriási kockázatokat hordoz.

Ha csak a legáltalánosabb, de minden szempontból a legsúlyosabb összegző adatokat nézzük 2021. július elejéig globálisan, Európában és a Kárpát-medence országaiban (1. táblázat), akkor azt kell megállapítanunk,

1. táblázat | A regisztrált Covid-fertőzések és a halálozások számának alakulása a világon, Európában és Magyarország szomszédságában 2021. július 3-ig

\begin{tabular}{lrrr}
\hline Terület, ország & A regisztrált fertőzöttek száma & A regisztrált halálozások száma & Az l millió lakosra jutó halálozások száma \\
\hline Világ & 183933740 & 3981758 & 510,9 \\
\hline Európa & 48160983 & 1105504 & 1699 \\
\hline Ausztria & 650662 & 10809 & 1182 \\
\hline Horvátország & 360067 & 8212 & 2013 \\
\hline Magyarország & 801721 & 29992 & 3113 \\
\hline Szerbia & 716717 & 7051 & 810 \\
\hline Szlovákia & 391696 & 12513 & 2291 \\
\hline Szlovénia & 257413 & 4419 & 2125 \\
\hline Románia & 1090860 & 33898 & 1774 \\
\hline Ukrajna & 2237202 & 52460 & 1207 \\
\hline
\end{tabular}

Forrás: Johns Hopkins University CSSE adatai alapján 
hogy a megbetegedések száma 2021 nyarára minden esetben nagyra nőtt. A megbetegedés valódi életveszélyt hordozott az egyének esetében, a halálozások száma magas lett. Az egymillió fơre eső halálozások száma - minden eltérés ellenére - minden országban döbbenetet váltott ki. Magyarországon éles vita bontakozott ki a kormány és az ellenzéki pártok között az adatok értelmezéséről.

Még súlyosabb lehet a valódi globális helyzet, mert a WHO véleménye szerint a globálisan regisztrált megbetegedésekhez és halálozásokhoz képest kétszer, de akár háromszor is magasabbak lehetnek a tényleges adatok, különösen a fejlődő országok adatainak hiányosságai és a látenciák miatt.

A járvány globális elterjedésében elsődleges szerepe lehetett a hatalmas, interkontinentális légi személyforgalomnak. Az IATA adatai szerint 2019-ben 4,5 milliárd utas „légi-közlekedett”, 46,8 millió járaton. 2020-ban alapvetően megváltozott a helyzet. (Nagy-Britannia repülőterei például 2019-ben 297 millió fós forgalmat bonyolítottak le. 2020-ban - fóleg nyáron - csak 74 millió fó vette igénybe a brit repülőtereket.) Az utasokkal együtt a repülőgépek a vírusokat is szállították, ezért alakultak ki az első nagy fertőzési gócpontok a nagy átszálló repülőterek térségében.

Az IATA a járvány kirobbanásától kezdve folyamatosan nyomon követte globális és kontinentális keretek között is a légiforgalmi korlátozásokat, s számolt azok hatásaival (https://www.iatatravelcentre.com/world. php). A legtöbb ország előbb a Kínával fenntartott menetrendszerü légi személyközlekedést függesztette fel, majd 2020 tavaszára lényegében megszűnt a menetrend szerinti interkontinentális légi személyközlekedés.

A Kínával szomszédos országok egy része (Mongólia, Oroszország) gyorsan, már 2020 januárjában a közös határszakasz lezárásával reagált. Hongkong is lezárta az anyaországi határait a magánjellegû személyforgalom előtt. 2020. március 31-re a világ bezárkózott: a világ népességének 91\%-a élt olyan országokban, melyek teljes vagy részleges határzárat alkalmaztak (https://www. pewresearch.org./fact-tank/2020/04/01). A „határzáró országok" a vírus terjedésének megakadályozását remélték, de csak részleges eredményeket értek el. (Bolíviában durva döntés született, ahol - belpolitikai okoknál fogva - a Chiléből hazatérni vágyó állampolgáraikat könnygázzal és gumilövedékekkel tartották távol a hazájuktól.)

Nem alakult ki egységes „járványvédelmi politika” (még a legegyszerúbb szakmainak tünő kérdésekben sem, hogy kell-e maszkot viselni, avagy sem), alapvető különbségek voltak a WHO, a vezető politikusok, sőt a járványügyi szakértők között is.

2020 januárjában sorban jelentették be az európai államok (Németország, Franciaország, Olaszország, Oroszország), hogy náluk is megjelent a koronavírus. Először az olasz kormány hirdetett ki egészségügyi szükségállapotot, január utolsó napján.
2020. január végén a WHO nemzetközi járvány-vészhelyzetet hirdetett, s kifejezetten magasnak minősítette a járvány kockázatait. Március 11 -én a WHO már egyértelműen világjárványról kommunikált (Ikotun et al. 2021).

Több ország kéthetes karanténba zárta a Kínából kimenekített saját állampolgárait (Ausztrália, Nagy-Britannia, Magyarország). Úgy vélték, hogy a személyi jellegú érintkezések megszüntetése megakadályozza az esetleges fertőzések továbbadását.

Ha a komplex járványkezelés hatósági eszközeit (kijárási tilalom, karantén, települési és területi vesztegzár, országos határzár) és eredményeit nézzük, akkor a számok tükrében azt fogalmazhatjuk meg, hogy Ausztrália kezelte - korántsem éles belső politikai és társadalmi viták nélkül - a legsikeresebben a folyamatokat.

\section{Az EU határpolitikai sajátosságai a járvány kirobbanásával párhuzamosan}

Az EU vezetése a járvány Kínában történt megjelenésével szinte egy időben kiemelt figyelmet fordított a járvánnyal kapcsolatos folyamatok alakulására (https:// www.consilium.europa.eu/hu/policies/coronavirus/ timeline). A horvát elnökség 2020. január 28-án aktiválta a járvánnyal kapcsolatos integrált válságelhárítási mechanizmust. Ettől az időponttól kezdve szinte folyamatosan az EU vezető szerveinek asztalán volt a vírussal kapcsolatos kérdések köre (köztük a határoké).

Az EU egyes tagállamai körében a járvány olaszországi megjelenése, majd tömeges berobbanásának időszakától kezdve felvetődött a belső határellenőrzés visszaállításának az ügye. A tagállami kormányok a saját lakosságuk védelme érdekében gyorsan kívántak lépni. (Március elején Dánia a fertőzöttek számának gyors növekedése miatt leállította a Svédország felé irányuló autó- és kompforgalmat, a német határon is csak dánokat engedtek belépni az országba.) A belső határok országonkénti zárásának-nyitásának teljes kronológiája (https://ec.europa.eu $>$ policies $>$ schengen $>$ docs) egy hosszabb füzet terjedelmű dokumentáció.

A belső határellenőrzés tekintetben Franciaország és Németország kulcshelyzetben volt a teljes szomszédsága irányába. Franciaország előbb Olaszország, majd Spanyolország felől érezte a vírusfenyegetettséget. Németország a „Schengeni határellenőrzési kódex” (2016/399 rendelete bázisán) a „közrend és a belső biztonság” fenntartása érdekében visszaállította a határellenőrzés rendszerét a déli határai mentén. Ezen belül engedélyezte az áruk és az ingázók korlátozott mozgását.

Az Európai Bizottság (március 13.) kifogásolta az egyoldalú döntéseket, s a belső határok korlátozásmentes nyitvatartása mellett foglalt állást. (Féltek a schengeni rendszer teljes összeomlásától.) A Bizottság olyan tervezetet készített március közepén, amely 30 napra javasolta lezárni a külső határon a személyek mozgását, melyen csak az EU polgárai léphetnének be, s mellettük csak or- 
vosokat, nővéreket, kutatókat engednének be. Az áruszállítás szabadságát fenn kívánták tartani. Az Európai Tanács - a tagállamok állam- és kormányfőinek teljes konszenzusával - március 17 -én „legkevesebb 30 napra” lezárta az EU külső határait. Az új helyzetben a külső határokon is minden körülmények között biztosítani kívánták az áruk szabad áramlásának a fenntartását (Schimmelfennig 2021).

A gazdaság múködése és a lakosság ellátása érdekében a tömeges szárazföldi árufuvarozás lehetősége a legtöbb határon fennmaradt. (Az Európai Unióban mintegy 3 millió ember érintett a távolsági teherszállításban.) Kamionvezetők tízezrei voltak és vannak úton Európában, akik - minden ténylegesen bevezetett és betartott óvintézkedések ellenére - nemcsak önmagukra nézve jelentenek kockázatot, de szélesebb értelemben a lakosság számára is.

A külföldön tartózkodó állampolgárok, a turisták, az üzleti úton lévők rendkívül kellemetlen helyzetbe kerültek a gyors döntések miatt. Nem egyszerüen anyagi nehézségek közé kerültek, hanem a bizonytalanság, sőt a kiszámíthatatlanság vált tömegek élményévé. A tagállami kormányok szervezték a külföldön rekedt állampolgáraik tömeges hazaszállítását. Az EU szintjén 2020. május 15-ig mintegy 600 ezer „kívül rekedt” polgár hazautazását szervezték meg.

Az Európai Bizottság az élelmiszer-ellátás biztosítása céljából március 30-án hivatalosan arra kérte a tagállami kormányokat, hogy engedélyezzék a mezőgazdasági idénymunkások és az egészségügyi dolgozók tömeges, határokon átnyúló áramlását.

Június 5-én a tagállami belügyminiszterek - a járványhelyzet javulása mellett - megállapodtak abban, hogy június végéig minden tagállam felszámolja a belső határokon az ellenőrzést és biztosítja a személyek szabad áramlását.

Június 30-án a Tanács - korántsem viták nélkül - ajánlást fogadott el arról, hogy meg kell kezdeni az utazási korlátozások feloldását bizonyos országok tekintetében. A tagállamok a saját céljaiknak megfelelően értelmezték az ajánlást.

Október 13-tól a Tanács ajánlása alapján bevezették a színkódok rendszerét az utazási korlátozások egységes kezelése érdekében. A helyzet függvényében rendszeres felülvizsgálatot helyeztek kilátásba.

Az oltóanyagok engedélyezésével és tömeges alkalmazásával 2021-ben új helyzet alakult ki (bizonyos mértékben oltás előtti - oltás utáni járványkezelési szakaszokról lehet beszélni). A határátlépési lehetőségeket már nemcsak a teszteléshez, hanem az oltás felvételéhez is kötötték.

Az Európai Bizottság a Schengeni Zóna teljes értékû múködésének a helyreállítását kezdeményezte (2021. 6. 2.). Úgy vélték, hogy az EU-n belüli szabad mozgás nem eshet áldozatául a Covid-vírusnak.

Megállapodás született az uniós digitális Covid-igazolványok bevezetéséről. 2021. július 1-től bevezetésre került az uniós zöld útlevél azok számára, akiket az Európai Gyógyszerügynökség (EMA) által engedélyezett vakcinával oltottak be. (A Magyarországon széles körben alkalmazott kínai és orosz vakcinák nem rendelkeznek általánosan elfogadott uniós mozgáslehetőséggel, országonként kell megállapodni róluk.)

A 2021. július elején az európai országokban még érvényben lévő határátlépési korlátozások (https://www. euronews.com/travel/travel-news) fokozatos feloldása megkezdődött. A nyitás öröme és a negyedik hullámtól való félelem egyszerre jelent meg.

\section{Magyarország: vírus, vírusválság, határzár-reakciók}

A világban és Európában kibontakozó vírusterjedés és válságjelek hatására létrejött, majd 2020. január 31-én megtartotta első ülését a Koronavírus-fertőzés Elleni Védekezésért Felelős Operatív Törzs (a továbbiakban Operatív Törzs) a belügyminiszter és az emberi erőforrások minisztere vezetésével. Az Operatív Törzs ülésein vitatta meg a soron következő lépéseket, s tett javaslatokat a kormány számára. Tájékoztatóin (https://koronavirus.gov.hu/intezkedesek) jelentették be az életbe lépő intézkedéseket, melyek az időszak kronológiailag rendezett, $s$ fontos forrásait is jelentik.

A különböző nemzetközi és hazai híradások arról számoltak be 2020. február 24-én, hogy az első regisztráltan pozitív teszteredményt mutató magyar állampolgár a Japán fóváros mellett karanténba helyezett Diamond Princess óceánjárón dolgozó magyar lett.

A koronavírus „igazoltan” 2020. március 4-én jelent meg Magyarországon, illetve az egészségügy számára. Az első két hivatalosan regisztrált magyarországi beteg Iránból visszatért, Magyarországon legálisan tartózkodó egyetemi hallgató lett. A két hallgató feltehetően február 22-én érkezett a Liszt Ferenc Repülőtérre, amikor Európában „a víruskérdés” már megjelent. A Kormány vírusvédelmi okokból március 6. után felfüggesztette az iráni állampolgárok számára szóló vízumok kiadását.

Március 11-én a kormány járványügyi vészhelyzetet hirdetett ki (az akkori hivatalos adatok szerint 15 fertőzött volt az országban), beutazási korlátozásokat vezetett be a leginkább „fertőzöttnek” tekintett országokból. Az országon belül még nem volt nyilvános információ a területi adatokról (Uzzoli et al. 2021).

Jelentősen érintette az ország nyugati határain való mozgáslehetőségeket, hogy a rendőrség március 12-től ideiglenesen visszaállította a határellenőrzést Ausztria és Szlovénia relációjában (www.police.hu/hu/hirek-es-informaciok/legfrissebb-hireink/hatarrendeszet/magyarorszag-ideiglenesen-visszaallitotta-a). Ausztria tekintetében a nemzetközi forgalom csak Hegyeshalom, Sopron, Rábafüzes határátkelőkön volt lehetséges. (A magyar és osztrák állampolgárok használhatták Fertőd, Kópháza, Köszeg, Bucsu, Szentpéterfa átkelőket is.) A szlovén szakaszon Tornyiszentmiklós és Rédics bonyolíthatta a 
nemzetközi forgalmat, a két állam polgárai ezen felül használhatták Pince átkelőjét is.) A zárások szaporodása miatt a rendőrség a honlapján március 15-én közzétette a „múködő határátkelőhelyek listáját”, térképmelléklettel együtt. A rendőrség hatalmas erőfeszítéseket tett a határforgalom mindenkori előírások szerinti lebonyolítására (Skorka 2020)

2020. március 15-én meghalt az első magyar koronavírusban szenvedő beteg. Elindult a folyamat új módon és új dimenzióban való kezelése. Magyarország március 17-én rendelte el a járványügyi határzárat, a hivatalos adatok szerint ekkorra 47 fertőzött volt az országban. A határzár időben jelent meg, s potenciálisan erőteljesen korlátozta a vírus további behurcolásának lehetőségeit (Hajdú-Rácz 2020)

Nem adtak a rendelkezés tudomásulvételére elég időt a külföldön dolgozó magyaroknak és a tranzitban érdekelt szomszédos országok állampolgárainak a felkészülésre, az utazásuk megszervezésére. A rendelkezések életbe lépése után több ezer ember torlódott össze $\mathrm{He}$ gyeshalomnál, több kilométeres kocsisor, többórás várakozás várt a belépni szándékozó magyarokra is. (A rendszerváltás óta nem tapasztalt állapotok alakultak ki a nyugati magyar határon.)

A határon kialakult torlódások, abnormális viszonyok miatt a kormány úgy döntött, hogy humanitárius folyosót nyit a Romániába, Szerbiába és Ukrajnába átutazni kívánók számára. A legnagyobb számban (mintegy 47 ezren) a román állampolgárok vették igénybe a lehetőséget.

Az ausztriai munkahelyek tömeges elvesztése, a határzár a határ magyar oldalán is sajátos folyamatokat indított el. Sopron, Kőszeg, Szombathely jelen lévő népessége jelentősen csökkent az ingázók tömeges belső településekre történő hazautazásával.

Március 28-tól a kormány kijárási korlátozásokat rendelt el április 11-ig, majd határozatlan időre. Március 30-án a parlamenti többség határozatlan időtartamra felhatalmazta a kormányt a rendeleti úton való kormányzásra.

Április elejére néhány, a tömeges idegenforgalomra berendezkedett település vezetése elkezdte korlátozni az „idegenek” (nem helyi lakosok) településre érkezését. Április 9-től már jogszabályi lehetőséget is teremtett erre a kormány, több település élt a „bezárkózás” lehetőségével. A félelem „másoktól” így elérte az ország lakosait is, különösen a budapestieket tették felelőssé azért, hogy a különböző korlátozások ellenére tömegesen utaztak a Balatonra, a Dunakanyarba stb.

Bár a tavasz nem igazán turisztikai főszezon, de a határzár életbe lépésekor mintegy 10 ezer magyar tartózkodott a világ különbözô részein magán és rövid hivatalos úton. Szijjártó Péter külügyminiszter április 8-i sajtónyilatkozata szerint addig az időpontig 8200 magyarországi lakóhelyű magyar állampolgár hazahozatalában segítettek a konzuli szolgálatok és a KKM. A külügyminiszter szerint „Magyarország modern kori története legnagyobb hazatérési akciója" volt ez. (Egészében véve mintegy 10 ezer magyar állampolgár hazaszállítása történt meg a határok lezárása után.)

A Kína-Magyarország közötti menetrend szerinti személyforgalmi légiközlekedési kapcsolatokat felszámolták. A járvány észak-olaszországi terjedése, a kialakult riasztó jellege miatt március 10. után a Liszt Ferenc Repülőtér nem fogadott járatokat Milánóból, Bergamóból és Trevisóból.

A járvány első hullámát sikeresen kezelte Magyarország. Menet közben kellett megteremteni a járvány megakadályozásának, a megbetegedettek gyógyításának feltételeit.

Május 3-án tetőzött a járvány első hulláma Magyarországon. 2020 nyara meghozta a „zárások” feloldását, a gazdasági szempontok, a turizmus igényei előtérbe kerültek. „Kiszabadult emberek ezrei” indultak turistaként Horvátországba.

A magyar-ukrán határon egyedül a Záhony-Csap vasúti és közúti átkelő volt nyitva. (Visszatért a járvány miatt a szovjet struktúra.) A két külügyminiszter június 25-én megállapodott, hogy megnyílik és múködni fog mind az öt kiépített határátkelő.

A stabil nyitás reményében a MÁV újraindította a nemzetközi, határon átnyúló vonatközlekedést július l-gyel, mégha nem is olyan gyakorisággal, mint a vírusjárvány előtt.

Az Európai Tanács kezdeményezte (ajánlotta), hogy a tagállamok nyissák meg július 1-tól határaikat 14 Unión kívüli ország állampolgárai számára. Magyarország csak Szerbia esetében alkalmazta az ajánlást. Július 4-én a kormányzat - román kérésre - újra humanitárius folyosót nyitott kelet felé. Az átutazók csak a kijelölt útvonalakon haladhattak, csak a kijelölt benzinkutaknál tankolhattak és pihenhettek, s csak meghatározott határátkelőhelyeken léphettek ki az országból. A folyamatot a rendörség és a hadsereg katonai rendészete vezényelte le.

A nyár végén már látszott a nagymértékű külföldi nyaralások hatása. A kormány az országokat három kategóriába (zöld, sárga, piros) sorolta a beutazás feltételei szempontjából. A két utóbbi kategóriából beutazóknak és hazatérőknek karanténba kellett vonulniuk.

2020. szeptember 1-től meghosszabbították a schengeni határok lezárását. A rendőrség mindössze 10 közúti határátkelóhelyen biztosította csak a személy- és teherforgalom beléptetését. Október l-tôl újabb egy hónapra meghosszabbították a határzár fenntartását.

2020. december 26-án „átlépte a magyar határt az első vakcinaszállítmány": Pfizer-BioNTech vakcina érkezett Hegyeshalomra. Az oltások megkezdésétől a határátlépések tekintetében nemcsak a tesztek, hanem egyre inkább a beoltottság került elötérbe, $s$ a védettségi igazolások váltak a legfontosabb bizonyító erejü dokumentumokká.

Közben megjelent az Egyesült Királyságban a vírus brit variánsa, mely fertőzőbb volt, mint a korábbi. Decemberben megtiltották az Egyesült Királyságból érkező 
repülőgépek leszállását, de 2021. január 5-én feloldották a tilalmat.

2021. február 25-én az Operatív Törzs bejelentette, hogy a vírushelyzet romlására való tekintettel a Kormány március 15-ig meghosszabbította a bevezetett korlátozásokat.

Magyarország 2021. június 24-től visszaállította az EU belső határokon a szabad mozgás lehetőségét. A Magyar Közlöny június 29-i számában megjelent kormányrendeletben foglaltaknak megfelelően a magyarukrán határon „ideiglenes határzár” lépett életbe, amely mind a személy, s első ízben a teherforgalmat is érinti. A kamionoknak Szlovákia felé kell kerülniük.

A nagy kérdés az, hogy 2021 „szabad nyara” mit hoz a továbbiakban. Mindenki tisztában van azzal, hogy a delta vírusvariáns terjedésével egy időben került sor a szinte teljes nyitásra (országon belül és a határokon átnyúlóan is), s mint Izrael példája mutatja, a magas szintű beoltottság ellenére elindult a negyedik hullám az országban.

\section{Közvetlen szomszédságunk határpolitikai folyamatai}

Magyarország földrajzi pozíciójánál fogva sajátos helyzetben van az EU-n belül, s különösen sokszínú szomszédsága tekintetében. Közvetlen államszomszédságunk többféle európai és kétoldalú határsajátosságot hordoz (1. ábra). Az „EU - nem EU” tagállam megkülönböztetés mellett a járványkezelési folyamatok szempontjából fontos „a Schengen - nem Schengen”, az euróövezeti hovatartozás és a NATO reláció is. A járvány súlyosbodásával párhuzamosan a NATO maga is kénytelen volt foglalkozni a válság biztonság- és katonapolitikai hatásaival. Az eurózóna pénzügyminiszterei elsősorban a járvány egyre szélesebben kibontakozó gazdasági hatásait elemezték rendszeres online konferenciákon.

A hét szomszédos ország eltérő sikerrel kezelte a vírusjárványt. Ausztria egy időben példa (laboratórium) volt Magyarország számára, más szomszédos országok felé (Románia, Ukrajna, Szerbia) a magyar kormányzat segítő jelleggel lépett fel. Minden uniós és egyoldalú magyar döntés szükségszerúen érintette a szomszédos országokat. Az Országgyúlés Hivatala folyamatosan tájékoztatta a képviselőket a járványhelyzet alakulásáról. A vírusjárvány kezelésének első szakaszával összefüggésben áttekintő kutatási összegzés készült a Kárpát-medence országairól a Nemzetstratégiai Kutatóintézetben (Balassa et al. 2020).

A szomszédos országok határpolitikai és határátléptetési gyakorlatát a budapesti nagykövetségeik és konzuli szolgálataik hivatalos dokumentumai, a „kinti” magyar nyelvư honlapok, valamint a magyar külügyminisztérium konzuli szolgálatának (https://konzuliszolgalat.kormany.hu/europa-utazasi-tanacsok) egyes országokra vonatkozó információi alapján fogalmazom meg röviden, nem megismételve a Magyarországgal kapcsolatban már említetteket.

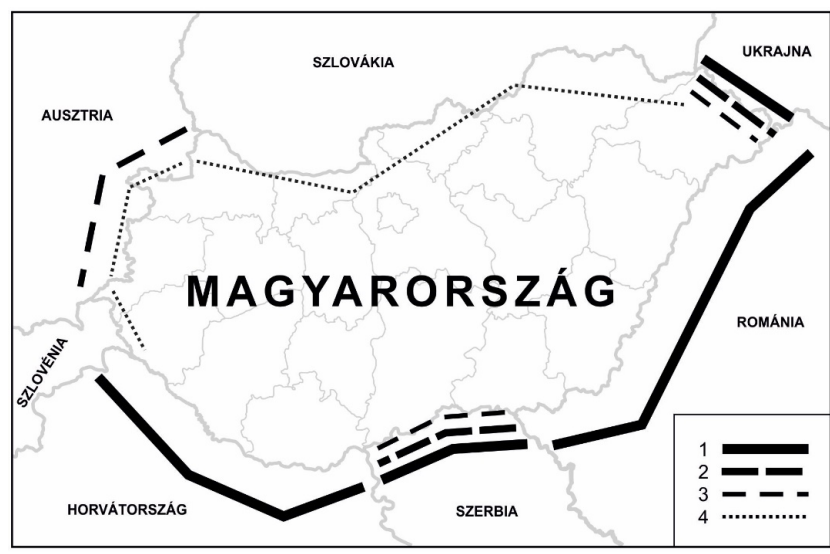

1. ábra

$$
\begin{aligned}
& \text { Magyarország „külső határ” sajátossága, 2020. } 01.01 . \\
& \text { Jelmagyarázat: 1 - schengeni külső határ; 2 - EU külső határ; } \\
& \text { 3 - NATO külső határa; 4 - eurózóna határa } \\
& \text { Forrás: saját szerkesztés }
\end{aligned}
$$

\section{Európai uniós és „schengeni” szomszédok}

Az osztrák-magyar határ ellenőrzésének kérdésköre, mely a vasfüggöny leomlásától valamilyen szinten folyamatosan jelen volt az osztrák oldalon, a 2015-ös migrációs válság időszakában került ismét a politikai viták homlokterébe. Ausztria mint „régi EU- és Schengen-zóna tag” alkalmazta az EU jogot és a schengeni határrezsimet.

A „vírusválság” időszakában természetes módon Ausztria is részese volt az „EU jogalkotásnak”, ugyanakkor megjelenítette saját érdekeit és elképzeléseit is (https://www.bmeia.gv.at/hu/osztrak-nagykoevetsegbudapest/). Ausztria sok tekintetben Németországgal párhuzamosan cselekedett. Ausztria előbb korlátozta a határforgalmat (március 13.), majd az EU egyeztetett döntés után teljesen lezárta saját határait. Március 13-án csak három magyarországi határátkelőn (Hegyeshalom, Rábafüzes, Sopron) tette lehetővé a nemzetközi teherforgalmat. A döntés nemcsak a határátkelőket érintette, hanem azt is jelentette, hogy a „zöldhatár átlépése jogellenessé vált", szabálysértési eljárást vont maga után.

Ausztria, s fóleg Tirol síterepei és szállodái az európai kiterjedésű járvány egyik „generáló központjának szerepét” töltötték be 2020 elején. (Ischgl település és egy bárja Európa-szerte hírhedtté vált.) A tiroli turisztikai központok kiürültek, s csaknem ezer magyar alkalmazott vált hirtelen munkanélkülivé. (Március 16-án karanténba helyezték Tirolt.)

Március 16-17. után a magyar-osztrák határon a rendszerváltás és a migrációs válság óta nem tapasztalt folyamatok bontakoztak ki, illetve az egyének számára súlyos állapotok alakultak ki.

A járvány kirobbanásakor az osztrák munkaügyi statisztikák alapján valamivel több mint 100 ezer magyar állampolgár dolgozott legálisan az egész országban. A napi ingázók döntő többségének Burgenlandban volt a munkahelye. Az Ausztriába naponta ingázó magyarok 
egy része (fóként a biztosnak tünő munkahellyel rendelkezők) úgy döntött a határ teljes lezárásától való félelmében, hogy kinn marad, és ott várja meg a fejleményeket, más részük hazautazott.

Ausztria sok tekintetben mind a belső korlátozásokban, mind pedig a szigorú, a rendelkezéseket betartó, határellenőrzések során tudatos vírusellenes védelmi gyakorlatot folytatott.

Ausztria, Csehország és Szlovákia külügyminiszterei 2020. augusztus 31-én még úgy foglaltak állást, hogy el kell kerülni a határok ismételt lezárását, de a magyar döntés miatt szeptembertól újra lezárásra került sor, Burgenland nehéz helyzetbe került. A határon keresztül napi ingázók kérdésköre folyamatosan napirenden volt, előbb a tesztelésekhez, majd az oltásokhoz kötötték a viszonylag szabad mozgásukat.

2021. július elején az ország fokozatos nyitásba kezdett. Nem szállhattak le repülőgépek Dél-Afrikából, Brazíliából és az Egyesült Királyságból (https://www. austria.info/en/service-and-facts/coronavirus-information).

Szlovákia 2020. március 13-tól visszaállította a határellenőrzést, ideiglenes rendszabályként csak a szlovák állampolgárok léphettek be az országba. Az áruszállítást nem korlátozták (https://korona.gov.sk/hu/elfogadott-intezkedesek/). Leállították a nemzetközi vasúti, autóbusz, vízi közlekedést. A légi közlekedés nagy része is megszünt.

Az ingázók mozgása rövid időre lehetetlenné vált. Ez elemi gondot jelentett a határon keresztül ingázók számára. Az egyének, családok életében bizonytalanság lépett fel, de a magyarországi foglalkoztatók számára is. Az esztergomi Suzuki és a győri Audi gyár munkarendátszervezésre kényszerült már a leállásról szóló döntés előtt. Az ingázók 30 kilométeren belüli viszonylag szabad mozgási lehetősége könnyített a helyzeten, s enyhítette a feszültségeket.

A kormány március 16-i hatállyal szükségállapotot hirdetett, a vírus veszélyességére való tekintettel. Szlovákia húsvét előtt külön rendszabályokat léptetett életbe, a belső és a határokon átnyúló mozgások tekintetében is. Április 8-10. között csak a következó átkelési pontok maradtak nyitva: Rajka, Vámosszabadi, Komárom, Esztergom, Parassapuszta, Balassagyarmat, Salgótarján, Bánréve, Tornyosnémeti, Sátoraljaújhely (https://www. korona.gov.sk).

Szlovákiában a járvány, illetve annak kezelése (az orosz vakcinához való viszony) jelentős belpolitikai vitákat generált, sőt sor került miniszterelnök-cserére is.

2021. március 18-án a szlovák kormány lényegében be- és kiutazási tilalmat rendelt el, betiltotta a külföldi üdüléseket, az indoklásban az szerepelt, hogy az üdülők ne hurcolhassák be a brit vírusvariánst az országba, ahol a járványhelyzet amúgy is súlyos. 2021. július elején Szlovákia határai átjárhatóvá váltak, kétoldalú megállapodások alapján elfogadják a magyar védettségi igazolást is (https://www.mzv.sk/web/en/covid-19).
Az északolasz járványgócpont közelsége, az intenzív személyes kapcsolatok és mozgások miatt a vírus szempontjából Szlovénia közvetlenül veszélyeztetett pozícióban találta magát a járvány kezdetén.

A viszonylag „csendes” szlovén határon Magyarország lépett elöször, március 13-án ideiglenesen - az osztrák szakasszal egy időben - visszaállította a határellenőrzést. Rövid időre leállt a személy és teherforgalom, csak magyar állampolgárokat engedtek belépni az ország területére. A nemzetközi határforgalom számára Rédics, Tornyiszentmiklós került kijelölésre. A magyar és szlovén állampolgárok számára Pince is használható maradt. Minden jármúvet és személyt megállítottak, s nyilatkoztattak arról, hogy mely területről érkezett a határra. Április 2-án újra megnyílt a két ország állampolgárai számára a bajánsenyei és a kétvölgyi határátkelő is.

2021. március elejére a járványhelyzet romlott az országban, ezért a schengeni belső határokon visszaállították az ellenőrző pontokat.

2021. július elején Szlovénia határai nyitottak az európai országok felé (https://www.gov.si/en/topics/coronavirus-disease-covid-19/border-crossing).

\section{EU tagállamok, de még nem schengeni zónán belüli szomszédok}

A magyar-horvát „határhelyzet” alapvetően az európai uniós döntéseknek megfelelően alakult. Mikrotérségi szinten kellett a két kormánynak sajátos megoldást keresni. 2020 tavaszán a muraközi horvát szőlősgazdák azt kérték a két állam illetékes szerveitől, hogy tegyék lehetővé számukra a Magyarországon fekvő szőlőterületeik múveléséhez szükséges oda-vissza átkelést (ingázást). A két külügyminisztérium rövid időn belül megállapodott az egyéni mozgások szabályozásáról. A két ország közötti mind a hét határátkelőn lehetővé vált a mozgás.

2020 nyara a magyar-horvát államhatáron a tömeges magyar kiutazások, tengerparti nyaralások jegyében telt el, melyek hozzájárultak a vírushelyzet romlásához. Szeptembertől nemcsak a magyar zárás, de a horvát belső szigorítások is új helyzetet teremtettek ismét.

Horvátország 2021. július elején megkezdte a határnyitást az oltási és védettségi igazolással rendelkezők előtt. Az EU/EEA térség minden országa „zöld listás” besorolást kapott. Az egyéb területek irányában még sajátos kikötések maradtak érvényben (https://mup.gov. $\mathrm{hr}$ /uzg-covid/english/286212).

A román állampolgárok tömegeit érintette a vírusválság a nyugati országokban, nagy számban veszítették el a munkahelyüket és életlehetőségüket. Tömegesen indultak meg gépkocsikon haza. A magyar-osztrák határra érve szembe találták magukat a határok lezárásával. Március 17-én Románia humanitárius folyosó megnyitását kérte. Magyarország rövid időn belül megnyitotta a humanitárius folyosót a román és bolgár állampolgárok számára, akik kijelölt útvonalon érkeztek a román átkelőhelyekre, s hagyhatták el Magyarország területét. 
A nagytérségi, határokon keresztüli vonulás után kistérségi kérdések kerültek előtérbe, mint a határon átnyúló ingázás kérdése. Néhány napos bizonytalanság után a VIII. román katonai rendelet április 9-én rendezte a magyar-román határon átnyúló ingázás romániai helyzetét. Az ingázónak - ha egészséges - nem kell karanténba vagy lakhely-elkülönülésbe vonulnia a munkába járása során. A rendelet területi hatálya azokra vonatkozik, akik bármely határátkelőtől 30 kilométeren belül élnek, s legalább hetente egyszer ingáznak a lakóhelyük és a munkahelyük között. A határok lezárása időszakában az ingázók csak a három (Létavértes-Székelyhíd, MéhkerékNagyszalonta, Nyírábrány-Érmihályfalva) kijelölt átkelőn keresztül mozoghattak, hosszú kerülőkkel és időveszteséggel. Április 10-től megnyílt számukra a Nagycsanád-Kiszombor, Nagylak-Nagylak, BattonyaTornya, Gyula-Gyulavarsád, Átánd-Bors, Vállaj-Csanálos, Csengersima-Pete átkelési lehetőség is.

A német mezőgazdaság munkaerő-szükséglete (a német mezőgazdasági miniszter szerint az ország mezőgazdasága áprilisra 40 ezer, májusra újabb 40 ezer fó idényfoglalkoztatott munkaerőt igényel) jelentős szívóhatást gyakorol ezen feltételek között is az olcsó keleteurópai munkásokra, az állásukat frissen elvesztettekre. Először a lengyel és a romániai munkaerő „mozdult meg”, lényegében a járvány közepén. Az adott határzárak és bizonytanságok között charter repülőgépekkel (szinte légihidakkal) szállítják a toborzott embereket. Kolozsváron botrányba fulladt április 9-én a repülőtéren mintegy 1500-2000 ember megjelenése. A toborzás jogszerű volt, a lebonyolítás módjából - a járványügyi elő́rások tömeges megsértéséből - azonban büntetőeljárás lett.

Ausztria bejelentette, hogy az egészségügyben és a szociális ellátás területén kialakult nagyfokú szakemberhiány felszámolására „zárt irányvonatokat” kíván szervezni Románia és Bécs között. Magyarországi megállások nélkül, éjszaka szállítanák át a romániai munkaerőt.

2021. július elején az EU/EEA térség állampolgárai számára szabad a beutazás Romániába, de az Egyesült Királyságra még kiegészítő feltételek vannak érvényben (https://romaniatourism.com/travel-advisory.html).

\section{Az EU-n kívüli szomszédjaink}

2015 óta a magyar-szerb határon folyamatosan „határhelyzet van”. A magyar múszaki határzár megépítése ténylegesen a határon átnyúló migrációs mozgások megakadályozását jelentette Magyarország felé. A kihívás folyamatos maradt, de részben szerb közremúködéssel sikerült megakadályozni a 2015-ös állapotok kialakulását.

A koronavírus megjelenésével és terjedésével párhuzamosan Szerbia is lezárta határait a személyforgalom előtt, mindössze három (Hercegszántó, Röszke, Tompa) határátkelőt hagyott nyitva a teherforgalom számára. Március 20-ra a teherforgalom bedugult, két-három napos várakozási időt igényelt a feltorlódott kamionok átkelése a határon.

A vajdasági magyar politikusok kezdeményezésére Magyarország Szerbiával is ki kívánja alakítani az ingázók „szabad mozgásának” feltételeit, de ez időigényesebb folyamat, mint ahogy a többi szomszédunk irányában megtörtént.

A magyar kormányzat nem járult hozzá, hogy - a román és ukrán megoldáshoz hasonlóan - humanitárius folyosót nyisson a fóleg Olaszországból és részben a német nyelvterületről hazatérő szerbiai vendégmunkások számára. Ezzel mintegy rákényszerítették Szlovéniát, Horvátországot és Szerbiát az ügyben való együttmúködésre. (A kérdést meg tudták oldani.)

2021. július elején az ország határai szelektív körben átjárhatóak (https://www.mfa.gov.rs/enthemes/covid1732020).

Ukrajna az EU külső szomszédjaként a legbonyolultabb helyzetbe került. Részben az EU, részben a magyar rendelkezések nehezítették meg a nyugati országokban és a Csehországban, Magyarországon, Szlovákiában dolgozó ukrajnai vendégmunkások hazatérését. Ukrajna első lépésként a március 15-29. közötti időszakra kiterjedően lezárta határait a külföldiek előtt. A magyar-osztrák határon a határzárak miatt feltorlódott ukránokat Magyarország humanitárius folyosón engedte át.

Időnként az ukrán döntések sem segítették a vendégmunkás tömegek helyzetének megoldását, hiszen bevezették (március 26.), hogy a saját állampolgáraikat sem engedték be. Az ukrán elnök azzal indokolta - a rövid ideig fenntartható döntését -, hogy választania kellett a járványhelyzet miatt a még külföldön maradt ukránok és az otthon élő mintegy 40 millió lakos biztonsága között.

Április 6-án lényegi változások léptek hatályba az ukrán kormány döntése következtében a közös határon. Megszünt a gyalogos, kerékpáros, mikrobuszos, buszos belépés lehetősége az átkelőkön. Csak saját tulajdonú személygépkocsival engedélyezik a belépést. A kisebb határátkelőkön való forgalom lehetőségét megszüntették a közös határon, csak Záhonynál lehet be- és kilépni a magyar szakaszon ukrán relációban. A vasúti személyforgalom felfüggesztésre került a két ország között.

2021. július elején az ország régiói három kategóriába vannak (sárga, narancs, piros) sorolva járványügyi tekintetben. Az ország határai személyforgalmi tekintetben erősen korlátozottan átjárhatóak (https://www.visitukraine.today).

\section{Összegzés}

A koronavírus tragikus, globális hatásai nemcsak a tömeges megbetegedések és halálozások tekintetében jelentek meg, de hihetetlenül rövid idő alatt minden országban romboltak a gazdaság, a társadalom, az oktatás, a kereskedelem stb. területén egyaránt.

A vírus terjedésének akadályozási szándéka (senki nem gondolta, hogy teljesen meg lehet állítani a mozgását) a 
sok mindenre kiterjedő belső korlátozások mellett, az államhatárok ellenőrzése, sőt védelme oldaláról is megjelent. A világ országainak döntő része 2020. március végére „bezárkózott”. Az EU maga is rákényszerült külső határainak lezárására, legalább a személyi mozgások tekintetében. A gyors, felkészülésre, alkalmazkodásra lényegében időt nem adó döntések tömegeket hoztak nagyon kellemetlen, kényelmetlen, sőt veszélyes helyzetbe.

2020 nyara a nyitást hozta világszerte, majd az ôsz a szinte teljes „újra bezárkózást”. 2021. kora nyara most már a tömeges oltakozás és védelem mellett az ismételt, szinte teljes nyitást hozta meg. Ez a nyitás más feltételekkel történt, mint a korábbi, de az igazi kérdőjel az, hogy maga a vírus is megváltozott, $\mathrm{s}$ az ismert és még nem ismert variánsok milyen hatással lesznek, akár az oltakozottakra is.

Magyarország az elsők között zárta le határait, s az általános európai folyamatoknak megfelelően nyitottzárt. Ugyanebben a szakaszolt folyamatban éltek a szomszédos államok polgárai is.

A járvány hosszú távú hatásai még nem mérhetők fel, de az biztos, hogy a tömeges, határokon átnyúló mozgásokat (történjen bármilyen közlekedési eszközön a luxus óceánjárótól a mikrotérségi gyalogos forgalomig) befolyásolni fogja a jövőben. A tragédia jelenlegi szintjén is mindenkinek újra kell gondolnia lehetőségeit és szükségleteit. Az újragondolásban nem a profit, nem az élmény maximalizálása, hanem a biztonságra való törekvés fog vezérelvvé válni.

Európa politikai és tudományos közössége mintegy két évtizeden keresztül a „határok megszűnéséről”, „határtalan Európáról”, a „határok virtualizálódásáról” stb. beszélt, értekezett, tervezett. Egy súlyos járvány szinte „pillanatok alatt” negligálta ezeket a törekvéseket. Az európai és tagállami döntések a valóságban „légiesítették” - legalábbis egy időre - az államhatárokon átnyúló, különböző jellegű regionális szerveződések munkáját. A központi államhatalmak Európa-szerte főszereplővé váltak az államhatárokon.

Egészében véve az egész vírusválság egyik legalapvetőbb kihívása az, hogy a globálisan megjelenő válságot hogyan lehet kontinentálisan, nemzetállami keretek között kezelni. Ausztrália példája azt mutatja (a maga sajátos földrajzi adottságai között), hogy a nagyon tudatos, néha drasztikusnak is nevezhető kormányzati beavatkozással lehetett csökkenteni a veszély nagyságát. Az Európai Unió - Ausztráliától eltérően - nem „elszigetelt” földrajzi egység, az EU esetében a rövid időn belül kialakult „vírusközösség” feltehetően erőteljesebben összehangolt védekezéseket követelt volna, illetve ki fog kényszeríteni a jövőben.

\section{Köszönetnyilvánítás}

A kutatás az NKFI 124903. számú OTKA keretében folyik.

\section{Irodalomjegyzék}

Balassa E., Bálint K., Farkas-Kordonec G., Gabri, R. \& Gubik L. (2020) A Kárpát-medencei országok koronavírus elleni védekezést szolgáló intézkedéseinek összehasonlító tanulmánya. Budapest, Nemzetstratégiai Kutatóintézet

Euronews. The travel restrictions in place in every country in Europe. https://www.euronews.com/travel

European Commission 2020: The effect of COVID-19 induced border closures on cross-border regions. An empirical report covering the period March to June 2020. Publication office of European Union, MOT

Hajdú Z. \& Rácz Sz. (2020) Államhatár politikák az Európai Unióban és Magyarországon a globális koronavírus-válság kezdeti időszakában. Tér és Társadalom, Vol. 34. No. 2. pp. 202-210.

Ikotun, O., Akhigbe, A. \& Okunade, S. (2021) Sustainability of Borders in a Post-Covid-19 World. South African Journal of Political Studies, Vol. 48. No. 2. pp. 297-311.

Országgyúlés Hivatala (2020) Az új koronavírus járvány kapcsán hozott járványügyi intézkedések az Európai Unió egyes országaiban. Budapest, Képviselői Információs Szolgálat

Schimmelfennig, F. (2021) Rebordering Europe: external boundaries and integration in the European Union. Journal of European Public Policy, Vol. 28. No. 3. pp. 311-330.

Skorka T. (2020) Rendőrség a koronavírus ellen. Magyar Rendészet, 2020. No. 4. pp. 173-192.

Uzzoli A., Kovács S., Páger B. \& Szabó T. (2021) A hazai COVIDjárványhullámok területi különbségei. Területi Statisztika, Vol. 61. No. 3. pp. 291-319.

A cikk a Creative Commons Attribution 4.0 International License (https://creativecommons.org/licenses/by-nc/4.0/) feltételei szerint publikált Open Access közlemény, melynek szellemében a cikk bármilyen médiumban szabadon felhasználható, megosztható és újraközölhető, feltéve, hogy az eredeti szerző és a közlés helye, illetve a CC License linkje és az esetlegesen végrehajtott módosítások feltüntetésre kerülnek. 